\begin{abstract}
ARTICLE I
International Alliance Strategies: A Case Study of the Indonesian Medical Device Industry is an article written by Aluisius Hery Pratono and Rosalia Vita Septina Ratih. The article research gap from introduction is discussing about the unique features of the Indonesian institutional environment and the alliance strategies of foreign and local companies in the medical sector in Indonesia. The research gap addressed by addressing research questions on how pressure of institutional environment determines the multi national enterprises' engagement in Indonesia medical device industry, what are the alliance strategies between multinational companies and local firms in the medical sectors to respond to the policy, and why the multinational companies choose the strategy. This study as research contribution has the intention to address the primary research question on how institutional environment determines the choice of a strategic alliance in B2B. Future studies are encouraged to identify the impact of this policy. However, the number of observed multinational enterprises running a business in Indonesia was limited.
\end{abstract}

\title{
ARTICLE II
}

Researching religious tolerance education using discourse analysis: a case study from Indonesia is an article written by Teguh Wijaya Mulya and Anindito Aditomo. The article keywords are religious tolerance, religious education, discourse analysis, and Indonesia. Through article introduction there is a research gap related to the lack of the utilisation of discourse analysis within religious tolerance education in Indonesia. It addressed by highlighting the ways in which discourse analysis may enrich and contribute to studies on religious education the promotion of religious tolerance. The research contribution of the article is by drawing on a discourse of tolerant theologies that might help to destabilise such dichotomy. Future studies' research gap are to explore the limits of tolerance as a discourse, such as the (im)possibility to draw on the discourse of tolerance to allow inter-religion marriage, same-sex marriage or atheism in a context like Indonesia and utilise discourse analysis to further explore such discursive contestations in other religious education and generate alternative knowledge to advance research on and the promotion of religious tolerance in education. 
Articles :

Pratono, A. H. And Ratih, RVS (2019) International Alliance Strategies: A Case Study of the Indonesian Medical Device Industry, in Faqih, N. (ed). Globalization and Development, Switzerland: Springer, pp. 381-400

Teguh Wijaya Mulya \& Anindito Aditomo (2018): Researching religious tolerance education using discourse analysis: a case study from Indonesia, British Journal of Religious Education 